\title{
Idiopathic hypereosinophilic syndrome in a rottweiler: a case report
}

\section{Síndrome hipereosinofílica idiopática do rottweiler: relato de caso}

\author{
Paulo Eduardo Ferian ${ }^{1 *}$; Eloisa Carla Bach ${ }^{1}$; Fabiano Zanine Salbego ${ }^{1}$; \\ Lusiane Zorzi Madaloz'; Julieta Volpato'; Thiago Rinaldi Muller ${ }^{1}$; \\ Rubens Antônio Carneiro ${ }^{3}$
}

\begin{abstract}
Eosinophils are cells of the immune system that have several important functions including phagocytosis of microorganisms, antigen presentation, contribution to chronic inflammation, and immunity against parasites. The hypereosinophilic syndrome (HES) is a rare disease in humans that is characterized by persistent eosinophilia (over six months) and variable eosinophil infiltration in organs such as the lungs, spleen, liver, lymph nodes, bone marrow, and gastrointestinal tract. Once in the tissues, these cells can cause damage by various mechanisms such as release of cytotoxic oxygen free radical and proteins. No etiology has yet been established for HES. The clinical signs vary and relate to the organs involved. In veterinary medicine, the disease has been described in cats, but rarely in dogs, with Rottweilers apparently more predisposed to developing the disease. Owing to the small number of cases reported in the veterinary literature, the prognosis of this disease and the most appropriate treatment options are unclear. Although it can be fatal in animals showing severe clinical symptoms, spontaneous remission may also occur. This study reports a case of HES in a Rottweiler in which the predominant clinical sign was abdominal effusion. We discuss the clinical and laboratory aspects of the disease.
\end{abstract}

Key words: Abdominal effusion. Dog. Eosinophils.

\section{Resumo}

Os eosinófilos são células do sistema imunológico que tem importantes funções, tais como fagocitose de micro-organismos, apresentação de antígenos, contribuição para a cronicidade do processo inflamatório e imunidade contra parasitas. A síndrome hipereosinofílica (SHE) é uma enfermidade rara que acomete seres humanos, caracterizada por eosinofilia periférica persistente (acima de seis meses) e infiltração variável de eosinófilos em diferentes órgãos, como pulmão, baço, fígado, linfonodos, medula óssea e o trato gastrointestinal. Uma vez nos tecidos, essas células causam danos por diversos mecanismos, como liberação de proteínas citotóxicas e radicais livres de oxigênio. Não é possível identificar uma etiologia nos casos de SHE. Os sinais clínicos são variáveis, e diretamente relacionados com os órgãos acometidos. Em medicina veterinária, a moléstia já foi descrita em felinos, mas raramente em cães, sendo que animais da raça Rottweiler são mais predispostos ao desenvolvimento da doença. Em função do pequeno número de casos descritos na literatura veterinária, a evolução da doença e as opções mais apropriadas de tratamento são pouco conhecidas. Embora alguns animais apresentem sinais clínicos graves, podendo evoluir para o óbito, a remissão espontânea também pode ocorrer. O presente trabalho tem por objetivo relatar um caso de SHE com sinal clínico predominante de efusão abdominal em um filhote de cão da raça Rottweiler, abordando aspectos clínicos e laboratoriais da enfermidade.

Palavras-chave: Cão. Efusão abdominal. Eosinófilos.

\footnotetext{
${ }^{1}$ Profs., Universidade do Estado de Santa Catarina, UDESC, Lages, SC, Brasil. E-mail: pauloeduferian@yahoo.com.br; eloisabach@yahoo.com.br; salbegocav@gmail.com; jully_volps@hotmail.com; mullerusa@hotmail.com.

2 Discente, UDESC, Lages, SC, Brasil. E-mail: lusianeanezo@hotmail.com

3 Prof., Universidade Federal de Minas Gerais, UFMG, Belo Horizonte, MG, Brasil. E-mail: rubenscarneiro55@yahoo.com.br

* Author for correspondence
} 


\section{Introduction}

Eosinophils are leukocytes that have phagocytic and bactericidal properties. They act as antigenic cells, contributing to chronic inflammation and fibrosis, and attacking parasites in both larval and adult stages. A number of diseases are associated with an increase in the number of eosinophils including cancer, vascular disease, parasitic infection, and allergic conditions (SYKES et al., 2001). The release and accumulation of eosinophils can be mediated by mast and basophils cell degradation products, deposition of immune complexes in tissues, vasoactive amines, and the production of cytokines (e.g. IL-2 and IL-5 from T lymphocytes), and complement derived chemotactic factors (PERKINS; WATSON, 2001).

The hypereosinophilic syndrome (HES) is a disease that has been reported in man, which is defined by persistent peripheral eosinophilia (over six months), no identification of an etiologic factor, and the presence of symptoms related to eosinophilic organ infiltration. HES has been described in cats and more rarely in dogs (LILLIEHÖÖK; TEVDTEN, 2003; PERKINS; WATSON, 2001). Any organ can undergo infiltration and subsequent tissue damage by eosinophils with the lung, spleen, liver, lymph nodes, bone marrow, and gastrointestinal tract most commonly affected. As a result the clinical signs of the disease are extremely varied (FIGHERA et al., 2004; PERKINS; WATSON, 2001; SYKES et al., 2001). Rottweilers appear predisposed to the development of eosinophilic disorders, such as eosinophilic meningoencephalitis and HES (BENNET et al., 1997; LILLIEHÖÖK et al., 2000; NDIKUWERA et al., 1992; SYKES et al., 2001).

Because of the limited number of cases that have been reported in the literature, the prognosis and appropriate treatment for this disease remain poorly understood. Therapeutic options in veterinary medicine mainly include the use of steroids and hydroxyurea. Spontaneous remission of the disease has been described in a Rottweiler (JAMES;
MANSFIELD, 2009).

In this study, we describe a case of HES in a Rottweiler dog. We discuss the clinical aspects and disease evolution.

\section{Case report}

An 8-month-old male Rottweiler dog was treated at the Veterinary Clinic of the University of Santa Catarina State (UDESC - Lages). The dog had shown clinical signs consistent with an increase in abdominal volume over the previous three weeks and exercise intolerance. The animal had received routine vaccination (three doses of the eightfold canine vaccine) and an anthelmintic had been administered (a solution of praziquantel, pyrantel pamoate, and febentel) approximately eight days before. During the physical examination, we observed a severe abdominal distension. Other clinical parameters were within normal limits. Because we suspected an abdominal effusion, an ultrasonography examination was requested, which showed moderately echogenic free fluid in large quantities. No other sonographic changes were observed. An abdominocentesis was performed in which a large volume of effusion was drained that had a serosanguineous appearance. The laboratory evaluation of the abdominal fluid was compatible with an eosinophilic exudate. The total nucleated cell count was 5,200 cells $\mu \mathrm{L}^{-1}$, with a predominance of mature eosinophils $(55 \%)$, rods (15\%), and metamyelocytes (2\%) (Figure 1A). The hemogram showed peripheral eosinophilia, in the presence of mature eosinophils and rods (Table 1 ). The biochemistry results and chest $X$-rays were not significant. The stool test showed the presence of Trichuris vulpis. The stereoscopic microscope evaluation of the abdominal fluid did not find any parasites. Fenbendazole $(1,500 \mathrm{mg} /$ day for three days) was prescribed to treat the trichiuriasis. After two weeks, the animal showed no abdominal distension and the owner reported an excellent overall condition. Ultrasonography did not indicate 
the presence of any free fluid, but the hemogram showed that the eosinophilia was still present (Table 1). After a month, another hemogram was performed (showing persistent eosinophilia) and a bone marrow aspiration was conducted (Figure 1B). The myelogram showed an increase in all the cells of eosinophilic lineage, including myelocyte $(0.35 \%$; reference $0.0 \%)$, metamyelocytes $(3.15 \%$; reference $2.4 \%)$, rod $(3.7 \%$; reference $0.9 \%)$, and mature eosinophils $(5.11 \% ; 0.3 \%$ reference). We performed further hematological evaluations in the patient after six and 18 months. In March 2014 and March 2015, blood samples were obtained from the mother of the patient. These showed a persistent peripheral eosinophilia (4,920 and 3,091 cells $\mu \mathrm{L}^{-1}$, respectively; reference $\left.100-1,250 \mu \mathrm{L}^{-1}\right)$.

Figure 1. Eight months old, male Rottweiler dog. A. Photomicrograph of abdominal effusion showing an abundance of eosinophils in different stages of maturation (arrows). B. Photomicrograph of myelogram, showing pronounced eosinophilic hyperplasia. $100 \times$ magnification. Source: prepared by the authors.
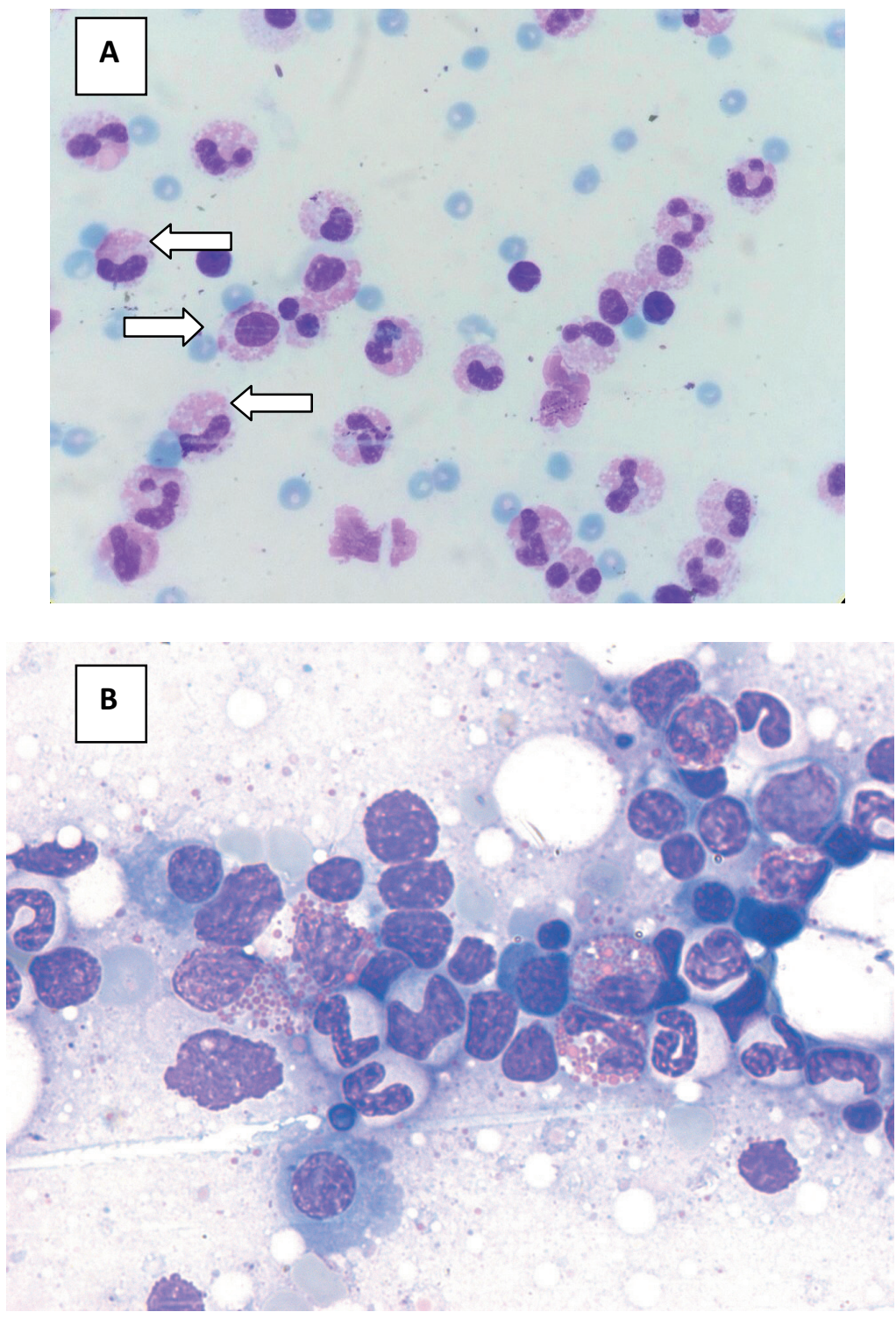
Table 1. Leucogram results in a Rottweiler male dog with HES. Lages, 2015.

\begin{tabular}{lccccc}
\hline \multicolumn{1}{c}{$\begin{array}{c}\text { Parameters } \\
\left(\text { cells } \boldsymbol{~}^{-1}\right)\end{array}$} & $\begin{array}{c}\text { Day } \\
\mathbf{1 5 / 0 7 / 2 0 1 3}\end{array}$ & $\begin{array}{c}\text { Day } \\
\mathbf{0 6 / 0 8 / 2 0 1 3}\end{array}$ & $\begin{array}{c}\text { Day } \\
\mathbf{2 4 / 0 9 / 2 0 1 3}\end{array}$ & $\begin{array}{c}\text { Day } \\
\mathbf{3 1 / 0 3 / 2 0 1 4}\end{array}$ & $\begin{array}{c}\text { Day } \\
\mathbf{1 8 / 0 3 / 2 0 1 5}\end{array}$ \\
\hline Total leukocytes & 14.400 & 23.050 & 17.800 & 15.300 & 19.070 \\
Segmented neutrophils & $5.904(41 \%)$ & $10.142(44 \%)$ & $7.476(42 \%)$ & $7.344(48 \%)$ & $8.772(46 \%)$ \\
Lymphocytes & $1.152(8 \%)$ & $5.302(23 \%)$ & $3.382(19 \%)$ & $1989(13 \%)$ & $4.386(23 \%)$ \\
Eosinophils & $6.624(46 \%)$ & $6.685(29 \%)$ & $6.230(35 \%)$ & $4896(32 \%)$ & $4.577(24 \%)$ \\
\hline
\end{tabular}

References (cells $\mu \mathrm{l}^{-1}$ ): Total leukocytes: 6.00 - 17.0; Segmented neutrophils: 3.00 - 12.0; Lymphocytes: 1.0 - 4.90; Eosinophils: $1.0-1.25$.

\section{Discussion}

In humans, HES is characterized by persistent eosinophilia (above $1,500 \mu \mathrm{L}^{-1}$ cells for more than six months) without an obvious cause and evidence of multi-organ infiltration. Although there is no specific definition for dogs, the same criteria are generally used for diagnosis (PERKINS; WATSON, 2001; SYKES et al., 2001). In the present case, in addition to persistent peripheral eosinophilia, there was the evidence of abdominal effusion and bone marrow involvement. Despite the patient showing no evidence of involvement of the other organs that are commonly affected, such as liver and spleen, this be cannot ruled out as biopsy and histopathology was not performed. We could not determine the etiology in this case, the animal had trichiuriasis but peripheral eosinophilia and eosinophilic effusion are not generally associated with infection with this parasite. Moreover, despite treatment for the parasite the eosinophilia persisted. On this basis, we suggest that the observed changes are consistent with a diagnosis of HES.

HES can be difficult to diagnosis because of its similarity to other eosinophilic diseases such as pulmonary infiltrates with eosinophilia (PIE), eosinophilic meningoencephalitis, and eosinophilic gastroenteritis. In these disorders, organ involvement is restricted to specific sites (e.g. the lung in PIE) and peripheral eosinophilia may or may not occur. Moreover, eosinophilic hyperplasia in the bone marrow is not observed in this condition. Another disease that can be especially difficult to differentiate from HES is eosinophilic leukemia (EL). The main difference between the two is that in leukemic disease there are more circulating blasts and in the medulla and the disease shows a more aggressive course. However, this is not always evident, and in humans, HES can even evolve into EL. Hence, some cases are a major diagnostic challenge. In our patient, there was no evidence of circulating blasts, and the favorable clinical progress ruled out the possibility of EL (LILLIEHÖÖK et al., 2000; PERKINS; WATSON, 2001; SYKES et al., 2001).

HES is rare in dogs, there have only been 13 cases in the literature with the first case reported in 1983 (GOTO et al., 1983). Of the reported cases, more than half have been Rottweilers (AROCH et al., 2001; DROUOT et al., 2007; FIGHERA et al., 2004; JAMES; MANSFIELD, 2009; JENSEN; NIELSEN, 1992; NDIKUWERA et al., 1992; PERKINS; WATSON, 2001; SYKES et al., 2001). The Rottweiler is a breed that has a high frequency of eosinophilic disorders. In a Swedish study of 125 dogs with eosinophilia, 34\% were Rottweilers. The reason for this is still uncertain (LILLIEHÖÖK et al., 2000). Therefore, the presence of persistent eosinophilia observed in the patient's mother is interesting, despite the fact that the animal showed no symptoms of the disease. This suggests a possible genetic component in the exaggerated eosinophilic response observed in these animals. To the best of our knowledge, no previous study has shown a genetic relationship between two animals with hypereosinophilic syndrome. 
The symptomatology and severity of this disease varies depending on the organs affected. Eosinophils cause tissue damage because of the release of cytotoxic proteins, which induce degranulation of mast cells and thrombosis, increasing vascular permeability, mucus secretion, and smooth muscle contraction. Additional damage may be caused by reactive oxygen products. Eosinophils can also stimulate the formation of fibrosis. The organs most frequently affected by HES include the liver, spleen, lymph nodes, stomach, intestines, and lungs. In a report of three Rottweilers with HES, two had abdominal effusion, which agrees with our findings. The cause of the effusion in these cases is probably due to an increase in vascular permeability caused by eosinophils leading to fluid exudation in the abdominal cavity. Eosinophilic effusion is an important diagnostic finding that is highly suggestive of HES since very few medical conditions can cause this change. Bone marrow involvement was observed in all dogs in which myelogram examination was performed, and the hyperplasia was characterized as being of the eosinophilic lineage, as observed in our patient (JAMES; MANSFIELD, 2009; PERKINS; WATSON, 2001; SYKES et al., 2001).

We observed a benign progression of the disease in the follow-up period in this case with a remission of the ascites and no evidence of progression to other organs despite no therapeutic drug intervention. The animal remained asymptomatic 20 months after the initial diagnosis. Spontaneous remission of the disease has been reported in a Rottweiler in Australia, with no recurrence of symptoms for more than four years after the initial presentation (JAMES; MANSFIELD, 2009). Some animals appear to develop milder forms of the disease. However, there are no predictive factors for disease progression in dogs, and most of the animals described have had severe signs and have needed treatment. Some have been euthanized due to the severity of their clinical symptoms. The first line of treatment for these patients is the use of steroids. For refractory cases, we recommend the use of hydroxyurea (DROUOT et al., 2007; PERKINS; WATSON, 2001).

\section{Conclusion}

HES is a rare condition that can develop into a dangerous clinic disease. The Rottweiler appears to be particularly predisposed to developing this disease. Very little is known about the causes, treatment and clinical evolution of this disease, and it is important that more studies about HES are conducted. The clinician should be able to recognize the disease, since the correct diagnosis and treatment can result in its remission.

\section{References}

AROCH, I.; PERL, S.; MARKOVICS, A. Disseminated eosinophilic disease resembling idiopathic hypereosinophilic in a dog. Veterinary Record, London, v. 149 , n. 13, p. 386-389, 2001.

BENNET, P. F.; ALLAN, F. J.; GUILFORD, W. G.; JULIAN, A. F.; JOHNSTON, C. G. Idiopathic eosinophilic meningoencephalitis in Rottweiler dogs: three cases (1992-1997). Australian Veterinary Journal, Victoria, v. 75, n. 11, p. 786-789, 1997.

DROUOT, S.; LOBSIGER, L.; HUBER, E. Acute idiopathic hypereosinophilic syndrome in a Rottweiler. Schweizer Archiv fur Tierheilkunde, Zurich, v. 149, n. 11, p. 511-516, 2007.

FIGHERA, R. A.; SOUZA, T. M.; KOMMERS, G.; BARROS, C. S. L. Síndrome hipereosinofílica idiopática associada à doença eosinofílica disseminada em um cão. Ciência Rural, Santa Maria, v. 34, n. 3, p. 939-942, 2004.

GOTO, N.; KAWAMURA, M.; INOUE, M.; SATO, A. Pathology of two cases of canine disseminated hypereosinophilic disease. Japanese Journal of Veterinary Science, Tokyo, v. 45, n. 3, p. 305-312, 1983.

JAMES, F. E.; MANSFIELD, C. S. Clinical remission of idiopathic hypereosinophilic syndrome in a Rottweiler. Australian Veterinary Journal, Victoria, v. 87, n. 8, p. 330-333, 2009.

JENSEN, A. L.; NIELSEN, O. L. Eosinophilic leukemoid reaction in a dog. Journal of Small Animal Practice, Oxford, v. 33, n. 7, p. 337-340, 1992. 
LILLIEHÖÖK, I.; GUNARSSON, L.; ZAKRISSON, G. Diseases associated with pronounced eosinophilia: A study of 105 dogs in Sweden. Journal of Small Animal Practice, Oxford, v. 41, n. 6, p. 248-253, 2000.

LILLIEHÖÖK, I.; TEVDTEN, H. Investigation of hypereosinophilia and potential treatments. The Veterinary Clinics Small Animal Practice, Philadelphia, v. 33, n. 6, p. 1359-1378, 2003.

NDIKUWERA, J.; SMITH, D.; OBWOLO, M. J. Chronic granulocytic leukaemia/eosinophilic leukaemia in a dog? Journal of Small Animal Practice, Oxford, v. 33, n. 11, p. 553-557, 1992.
PERKINS, M. C.; WATSON, A. D. J. Successful treatment of hypereosinophilic syndrome in a dog. Australian Veterinary Journal, Victoria, v. 79, n. 10, p. 686-689, 2001.

SYKES, J. E.; WEISS, D. J.; BUOEN, L. C.; BLAUVVELT, M. M.; HAYDEN, D. W. Idiopathic Hypereosinophilic Syndrome in 3 Rottweilers. Journal of Veterinary Internal Medicine, Philadelphia, v. 15, n. 2, p. 162-166, 2001. 